\title{
Improvement in the Efficiency of Investment Activity Management of Small Businesses in the Russian Federation
}

\author{
Alexander M. Adamchuk ${ }^{1} \&$ Denis E. Barkin ${ }^{1}$ \\ ${ }^{1}$ Gubkinsky branch of the Belgorod state technological University n. a. Century, Shukhov, Gubkin, Russian \\ Federation \\ Correspondence: Alexander M. Adamchuk, Ul. Victory, D. 48, square 1, Belgorod region, Gubkin, 309186, \\ Russia. Tel: 8-910-327-2914.
}

\author{
Received: March 30, 2015 Accepted: April 20, 2015 Online Published: May 14, 2015 \\ doi:10.5539/res.v7n7p231 URL: http://dx.doi.org/10.5539/res.v7n7p231
}

\begin{abstract}
Based on a comparative analysis of the Russian small business operating in the Russian Federation and economically developed countries, the present article reveals an insufficient level of small business development while it is highly important for the Russian economy's efficiency. This article justifies the value of investment activities for the operation of small businesses in the Russian Federation. It determines the tendencies of growth among unprofitable small businesses for the period between 2010 and 2013. Based on the analysis and consolidation of financial performance indicators of small businesses in the Russian Federation, we identified the main factors during the analyzed period, which constrained the investment activity of these entities in the current circumstances of the Russian economy development. The factors revealed include the following tendencies: lack of equity capital, low rate of return on the capital invested, and high value of debt capital. The article determines the main directions of investment activities within small businesses, which are characterized by the poor differentiation and subordinated nature of the economic and industrial activity of commercial entities. Taking into account the argumentation of inefficiency in the investment activity development of small businesses in Russia, the feasibility of using the J. Franshon and I. Romane's matrix of financial strategies is reasoned in order to form an optimal investment strategy on the example of the Vector-Plast company. The system of conceptual recommendations on improving the efficiency of the company's investment activity is suggested.
\end{abstract}

Keywords: investment activities of a small business, investments, management of investment activity, investment strategy, financial strategy, the matrix of financial strategies, investment in fixed capital, financial resources, investment potential of small businesses, equity and debt capital of small entrepreneurship

\section{Introduction}

\subsection{Introduce of the Problem}

Small businesses form the economy basis in the Russian Federation (RF) being a state with a market economy, as they represent the most dynamic and widespread form of business activity of the society. The development of the small entrepreneurship sector largely determines the pace of economic growth, as well as the structure and quality of the gross national product (GNP). All-increasing importance of small businesses in the development of economic and business ties in Russia is one of the most important contemporary tendencies because small business takes on significant socio-economic functions providing conditions for the reproduction of market relations with regard to the balance of interests between supply and demand. Currently, the sector of small businesses in Russia is one of the most vulnerable structures in the domestic economy, which is associated with the investment activity subtleness of the given business entities.

\subsection{Importance of the Problem}

Effectiveness of the investment activity of small businesses is largely predetermined by management decisions. Timeliness and quality of such decisions enhance the company's competitiveness in the market and contribute to its financial development. Economic independence of small businesses within the severe competitive environment is enabled by the properly organized investment policy and monitoring of its implementation. Under these conditions, the problem of increasing the investment management efficiency of small businesses in the Russian Federation becomes a first priority scientific and practical task and determines the relevance of the 
research topic, purpose, and design.

\subsection{Relevant Scholarship}

An analysis of the results obtained while researching the leading scientists' developments, as well as the dedicated literature suggests a high level of theoretical elaboration of the subject matter concerning the investment activity management within small businesses. Among the papers of domestic and foreign scientists working in the field of research and evaluation activity, the most significant are those written by the following scientists: Barmashov (2013), Bocharova (2014), Korkmazova (2015), Lisin (2010), Metelkin (2012), Pinkovetskaya (2013), Savchenko (2013), Sukhova (2012), Zhabunin (2012), Khokhlova (2013), Yashin (2010), Bennett (2015), Erden (2005), Holcombe (2005), Shweta (2012) and others.

At the same time, scientific achievements and practical experience in the problematics still leave debatable both theoretical and practical aspects of this problem solution requiring further research. In particular, the issues of approach development and rationale for priority orientations to the improvement of the investment management efficiency among small businesses still remain unresolved. Especially, if we take into account the peculiarities of such businesses functioning at the present stage of the Russian economy development.

\subsection{State Hypotheses and Their Correspondence to Research Design}

Given the controversy and ambiguity of conceptual approaches in this scientific field, the purpose of this study is the theoretical justification for the development of theoretical and methodological support, which is provided to the investment activity management optimization of small businesses. Such optimization is based on the principles of determining the features of these business entities' investment activity at the present stage of the Russian economy development, as well as on the development of an investment strategy using the J. Franshon and I. Romane's matrix of financial strategies.

The present study is devoted to resolving a number of conceptual problems:

- Analyzing the current state of investment activity performed by small businesses in Russia;

- Determining the main factors of decrease in investment activity of small businesses;

- Justifying the ineffectiveness of investment activity management of small businesses in accordance with the modern tendencies of their operation;

- Developing conceptual recommendations on the improvement of the investment management efficiency of small businesses.

\section{Method}

In order to achieve the objectives and solutions of the problems defined, we used general scientific and ad hoc methods:

\subsection{The Method of Statistical Survey}

Within this study, the original database for evaluating the investment activity of small businesses in Russia during the period between January 01, 2012 and January 01, 2014 was formed using a random statistical survey. By means of scientific collection of information on the volume of commercial activities of small businesses in the GDP, the analytical basis for determining the importance of small entrepreneurship for the Russian economy was formed. Through generation of information on the financial results, equity capital, reserves, and the borrowing level of small businesses, the data on the potential of their investment activities were systematized. Collection of statistical indicators of financial statements in case of the Vector-Plast small enterprise allows forming a sample for determining the company's investment strategy.

\subsection{Methods of Analysis and Measurement}

Based on the formed databases concerning the efficiency of investment activities among small businesses in Russia, the temporary statistical summary was produced by means of the analysis method. The mentioned summary includes the following indicators: the ratio of small businesses in GDP of Russia; the relative dynamics of the financial results from operating activities of small businesses in Russia; the indicator of financial results from operating activities of small businesses; the indicator of forming proprietary investment resources; the indicator of the state of small business lending; the dynamic indicator of the growth rate among current obligations; the volume indicator of budgetary appropriations for the implementation of the federal budget program on supporting small and medium-sized entrepreneurship; the volume indicator of investment by small businesses into the equity capital; the quantitative characteristics of the factors constraining the investment activity of small businesses; and the indicator of the financial and operating performance of the Vector-Plast company. The 
statistical summary of quantitative data makes it possible to reveal the features of the investment activity of small businesses in Russia and to offer a practical approach to the management efficiency improvement by means of measuring relative indices and financial ratios.

\subsection{The Method of Structural Financial Analysis}

Indices of the Operating Performance (OP), Financial Performance (FP) and Financial and Operating Performance (FOP) were calculated by means of determining the structure of the final financial indicators and revealing the effect of each of these indicators on the overall operating performance in case of the Vector-Plast small enterprise for the period between January 01, 2012 and January 01, 2014. The system of indicators allowed us to determine the current financial strategy of the enterprise under study.

\subsection{Method of Financial Strategies}

The matrix of investment strategy quadrants was formed on the example of the Vector-Plast small enterprise during the period between January 01, 2012 and January 01, 2014 based on the methodological principles of the new management concept; taking into account the differentiation of types of the enterprise development strategies; and through the use of the J. Franshon and I. Romane's matrix of financial strategies. This approach allows us to carry out a realistic assessment of the following aspects: the investment opportunities of the company, provision of the maximum usage of its internal financial capacity, and the opportunity to handle actively its financial resources.

\section{Results}

In the circumstances of the functioning market economy, the small business sector is one of the leading sectors and determines the rate of the economic growth, as well as the structure and quality of the gross national product of any country. As shown in the analytical data, small business in the leading developed countries accounts for $30 \%$ to $80 \%$ of the state's GNP (Figure 1). Therefore, the vast majority of the developed countries encourages the activities of small businesses in every possible way. Importance of small businesses for the Russian economy in terms of its efficiency is significant, but the actual data reflect their weak development. The share of small businesses in the structure of Russia's GDP is only 21\% (Figure 1). The development level of this sector in Russia, as measured by international standards, is clearly insufficient. In addition, the average number of small businesses by 1,000 of the Russian population comprises only 6-7 companies, whereas in the EU member states this indicator is not less than 25-35 companies. (Khanna \& Tice, 2011)

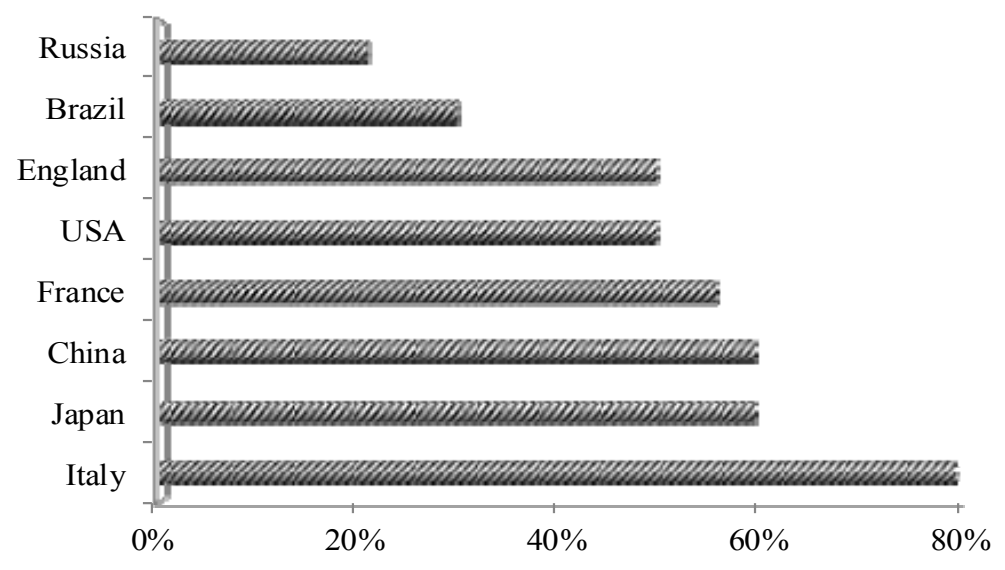

Figure 1. Percentage of small businesses in the GDP of the country as of January 01, 2014

Note. Compiled by the author according to the data of (Bank for Development and Foreign Economic Affairs. Bank for Development, 2015).

In addition, along with the overall positive growth tendency in the number of small businesses in Russia that has increased over the past four years almost by $156 \%$, there can be also observed a steady increase in number of loss-making small businesses by the results of their operating activities (Figure 2). Thus, despite the dominance of profitable enterprises in the structure of small businesses of Russia up to $77.2 \%$, during the period between 
January 01, 2011 and January 01, 2014, the percentage of unprofitable enterprises increased by $2.1 \%$ and reached the value of 262,767 as of January $01,2014$.

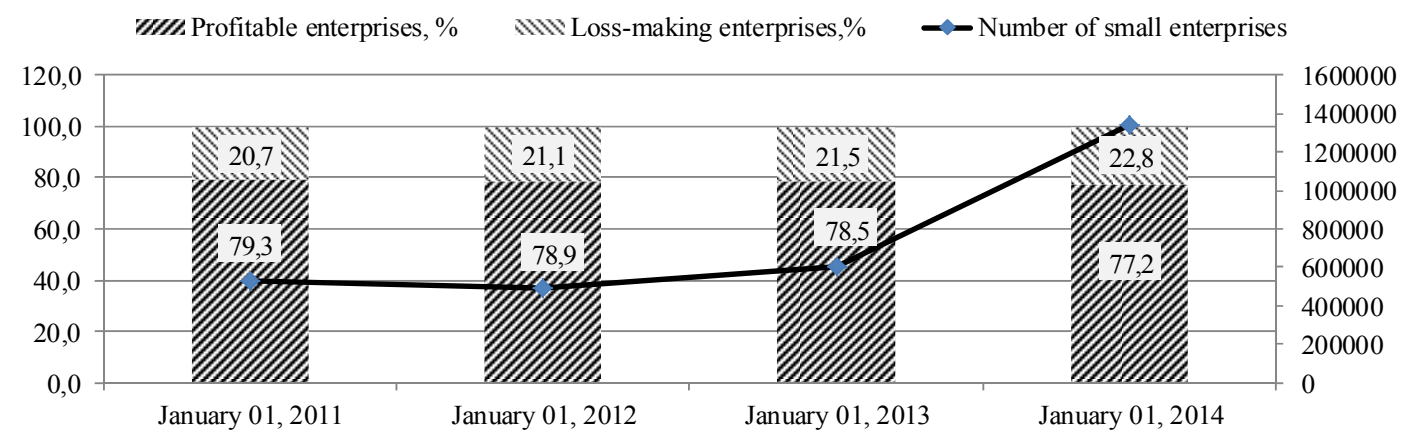

Figure 2. Relative dynamics of the financial performance of small businesses in the Russian Federation

Note. Compiled by the author according to the data of (Bank for Development and Foreign Economic Affairs. Bank for Development, 2015).

Analysis of the financial performance of small businesses suggests a parallel increase in profits and losses, and despite the decline in the loss share in the financial performance of small businesses by $16.3 \%$ during the period between January 01, 2011 and January 01, 2014, its percentage still remains substantial— 45.7\% (Figure 3).

The revealed development tendency of enterprises is negative and predetermines the reduction in the volumes of proprietary investment resource belonging to small businesses, which adversely affects their economic performance. Investment activities are extremely important for solving virtually all strategic and a considerable part of current development problems and for ensuring effective growth of small businesses' value in accordance with their economic policy chosen (Figure 4), which necessitates the formation of a sufficient amount of proprietary investment resources (Metelkin, 2012; Khokhlova, 2013).

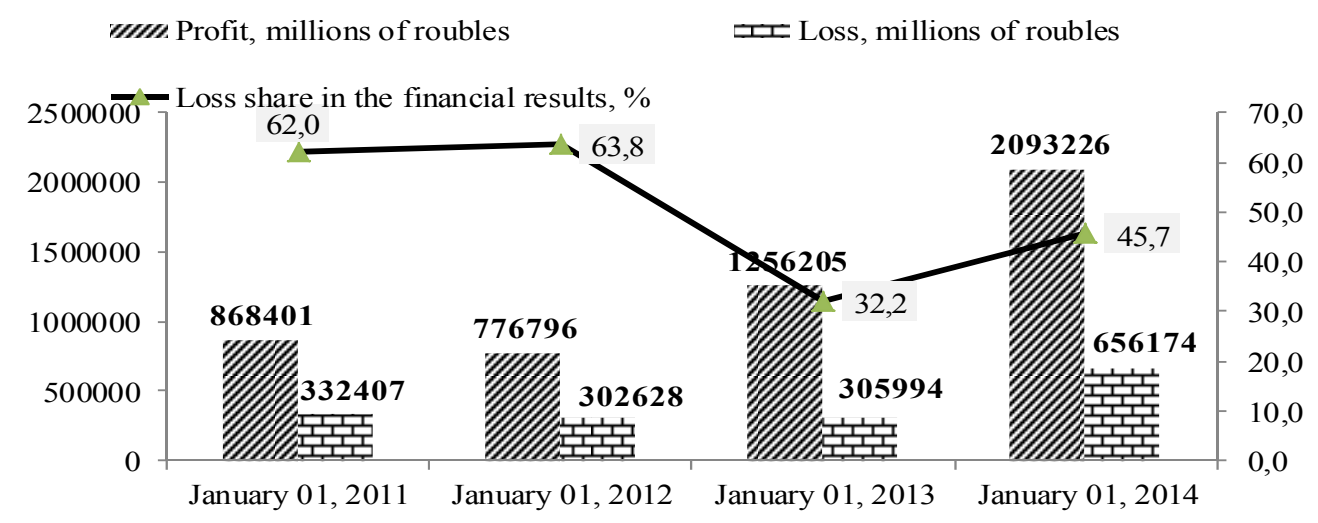

Figure 3. Indicators of financial performance of small businesses in the Russian Federation Note. Compiled by the author according to the data of (Federal State Statistics Service, 2015). 


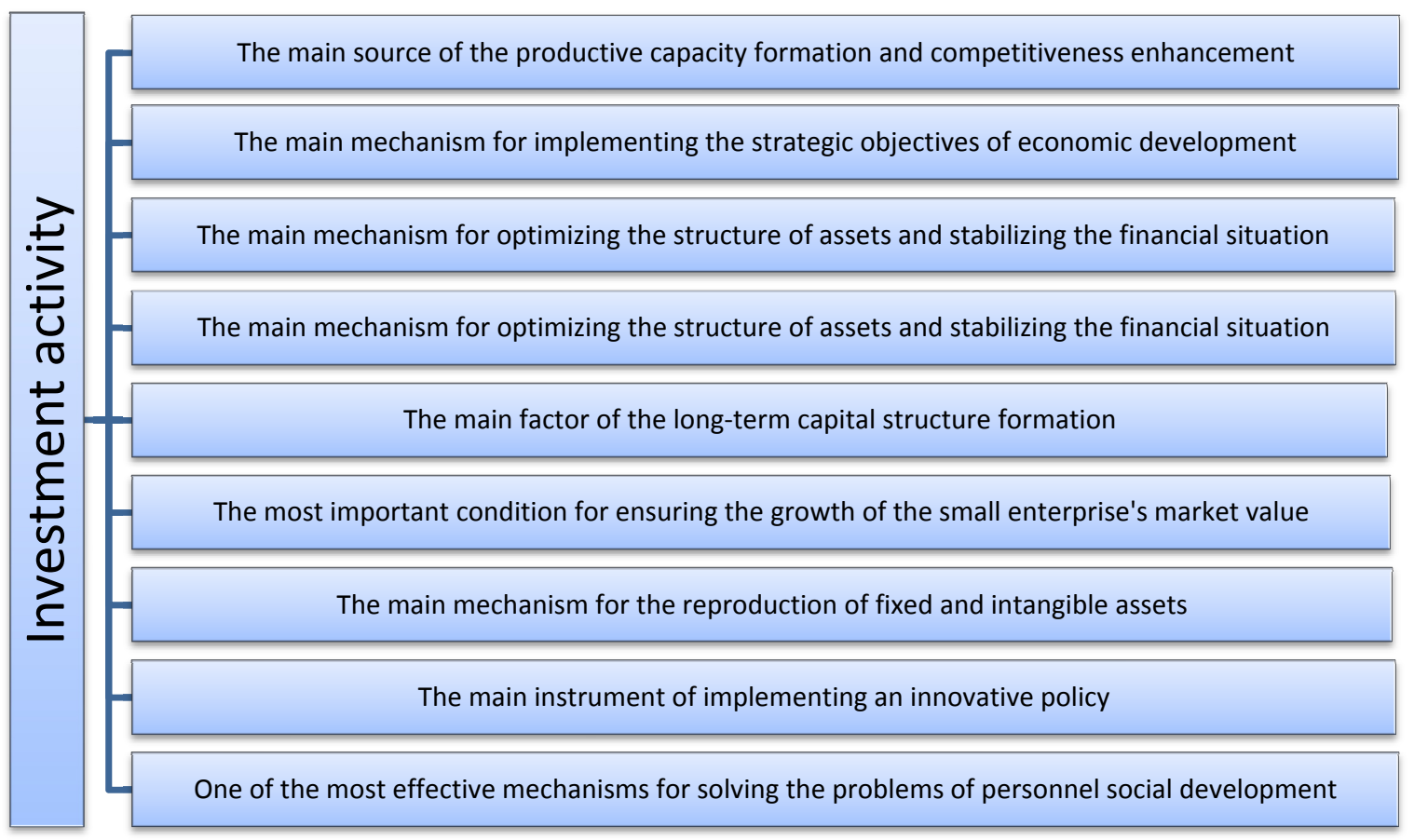

Figure 4. Importance of investment activity for the operation of small businesses

Note. Compiled by the author based on (Goryainova, 2011; Mukhametlatypov \& Dadakhanova, 2013; Savchenko, 2013; Bouchaud \& Potters, 2009; Erden \& Holcombe, 2005).

Proprietary investment resources have a number of advantages over other types of investment resources of small businesses, namely: simplicity, speed, and mobility of attraction, aimed at current and capital repairs, upgrading, modernization of fixed assets and intangible assets, increasing the size of the financial investments, and motivation of employees (Galliamova \& Kashin, 2011). The current state of the investment activity among small businesses in Russia gives reasons to conclude that their proprietary investment resources are not the source that can activate the investment process. Thus, with the growth of capital and reserves of the small entrepreneurship sector by $27 \%$ during the period under study, the ratio of financial autonomy tends to a sharp reduction from January 01, 2011 by $36.5 \%$ as of the beginning of the year 2014. This fact evidences the dominance of the debt capital in the structure of small businesses' capital (more than 80\%) (Figure 5).

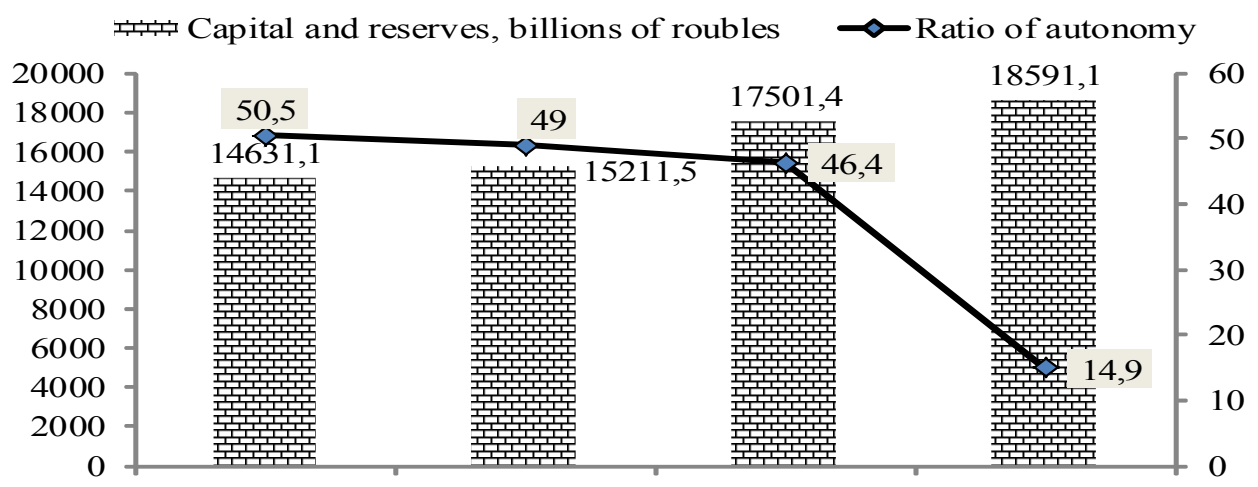

January 0 1, 2011 January 0 1, 2012 January 0 1, 2013 January 0 1, 2014

Figure 5. Indicators of forming proprietary investment resources of small businesses in Russia Note. Compiled by the author according to the data of (Federal State Statistics Service, 2015). 
The volume of the proprietary investment resources of small businesses is limited both by the high level of competition and the high level of shadow economy in this business sector and in the country as a whole (Pinkovetskaya, 2013).

One of the main sources of the small businesses' investment activity for today are credit resources of banks and other borrowings, which form the debt capital of businesses and increase the size of long-term and current debts (Bocharova, 2014; Korkmazova, 2015).

Herewith, the use of this type of investment resources contains certain risks for small businesses: if, in the course of their usage, they are transformed into slow assets or do not contribute to the increase in the active part of fixed assets, then the dependency of investment processes on the oscillations of the external environment grows (Yashin, 2010; Integrated Small-Enterprise Development Strategy, 2015).

As the analysis shows, at the current positive tendency of the growing borrowing by small businesses in Russia (the growth amounted to almost $68 \%$ for the period 2010-2014), a steady decline in the borrowing growth rate has been observed, and in 2014, the rate reduction amounted to 3.9\%. Along with the reduction of the borrowing growth rate, the level of loan debt among small businesses increases, which by the end of the period under study reached $74.8 \%$ of the share in the total volume of borrowing. In addition, an increase in the level of loan arrears among small businesses by $101 \%$ as of the end of 2014 was observed, which indicates deterioration of the payment discipline in this economy sector of Russia (Figure 6).

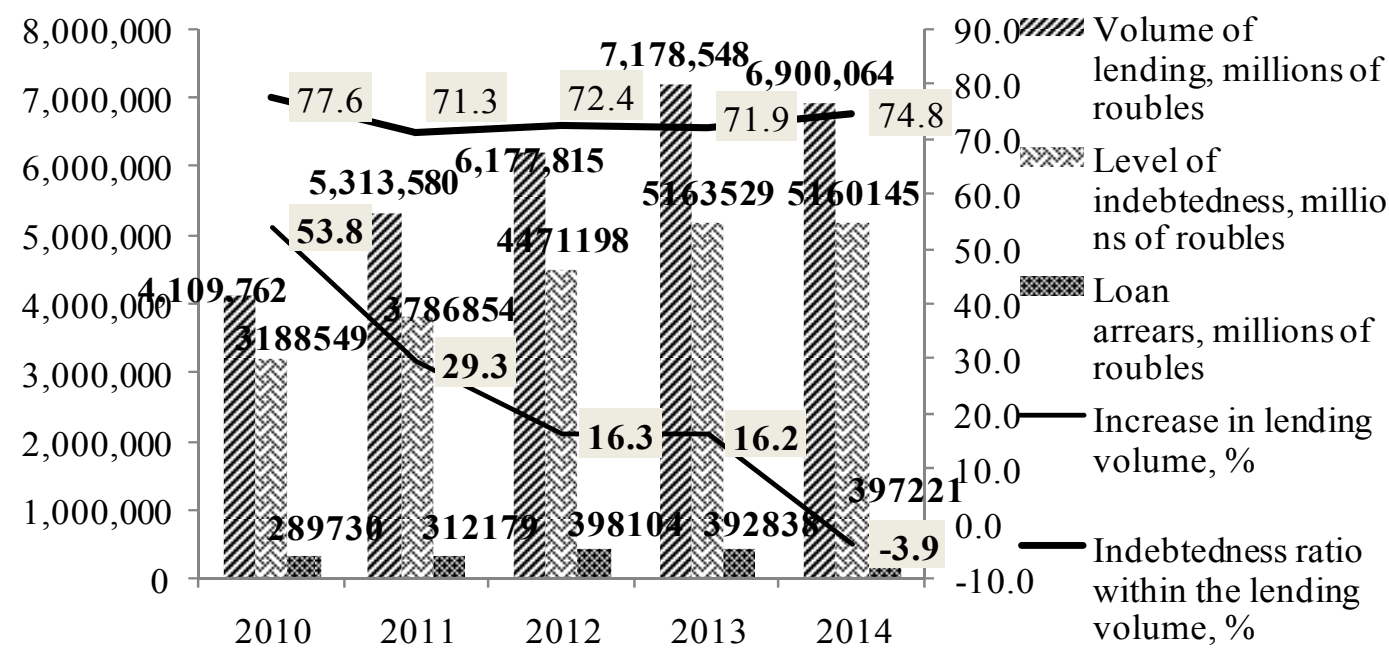

Figure 6. The state of borrowing with regard to small businesses in Russia

Note. Compiled by the author according to the data of (Central Bank of the Russian Federation, 2015).

In view of the identified tendencies, we can state the potential reduction in the investment resources formation among small businesses at the expense of bank credit resources. And given the fact that the study reveals a significant prevalence of borrowed resources in the structure of the small businesses' capital, we can state potential decline in the investment activity of the small entrepreneurship sector in Russia.

An alternative source of formation of the investment activity resources among small businesses is the attraction of financial resources by issuing securities and enlarging the volume of current liabilities (Shweta, 2012). At the Russian small businesses, attraction of investment activity resources is formed mainly by increasing current liabilities, as issuing securities is a privilege of joint-stock companies, and this economic activity is not inherent to small businesses (Bennett, 2015). Financial resources generated through this type of activity are short-term in nature; affect the working motivation due to the increasing debt in salaries and liabilities of the business founders, and influence on the state of payment discipline within the business (Barmashov et al., 2013). As the analysis demonstrates, this kind of resources for the small-sized entrepreneurship sector's investment activity in Russia also reduces the level of its potential. This is caused by the perceived moderation of growth rate due to the reduction in bank lending. Therefore, from the beginning of 2011 and up to the beginning of 2014, the growth rate of current liabilities decreased by 14.2\% (Figure 7). 


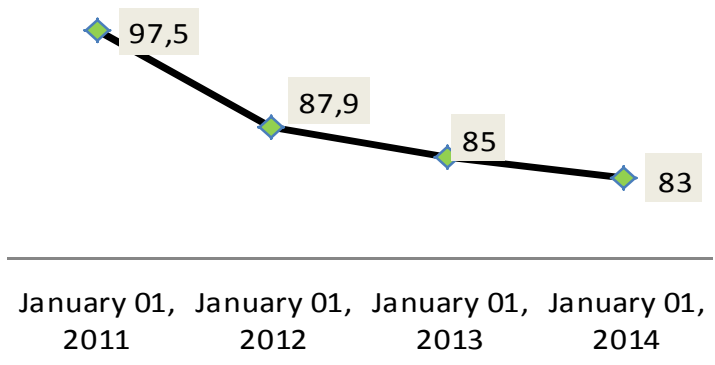

Figure 7. The growth rate dynamics of current liabilities of small businesses in Russia, $\%$

Note. Compiled by the author according to the data retrieved from (the Federal portal for small and medium-sized entrepreneurship, 2015).

Investment activity of small businesses in Russia is also characterized by the formation of investment resources at the expense of government subsidies. Since 2005, the Russian Economic Development Ministry has been implementing a special program to grant subsidies from the federal budget of the Russian Federation in order to provide the entities of the small and medium-sized entrepreneurship with the state aid at the regional level.

Currently, the program is implemented in accordance with the Resolution of the Government of the Russian Federation dated February 27, 2009 No. 178 "On the distribution and provision of subsidies from the federal budget of the Russian Federation for the state support of small and medium-sized entrepreneurship including peasant (farm) households", and in accordance with the annually published orders of the Ministry of Economic Development of the Russian Federation (Russia Government Resolution No. 178, 2009).

Within the program, all the funds are distributed on the earmarked and competitive basis between regions for the implementation of activities envisaged under the regional programs of development of small and medium-sized entrepreneurship under the condition of co-financing the expenditures by regional authorities. In addition to the federal budget funds, this approach allows us to raise regional funds and encourage regions for implementation of a more active policy in the field of entrepreneurial activity support.

As the analysis shows, the budget subsidy for small and medium enterprises in Russia demonstrates a growing tendency during the period under study. The increase in subsidies from the federal budget during the years 2010-2013 amounted to $11 \%$ (Figure 8). At the same time, the share of the budget funds is only $0.6 \%$ of the total amount of funds involved in investment activity of small businesses, which indicates the insufficient volume of budget financing assigned for these business entities.

Thus, the investment activity of small businesses at the present stage of their development is characterized by the unworthiness of its provisional resources, both from the perspective of fixed capital formation and the financial funds borrowing opportunities.

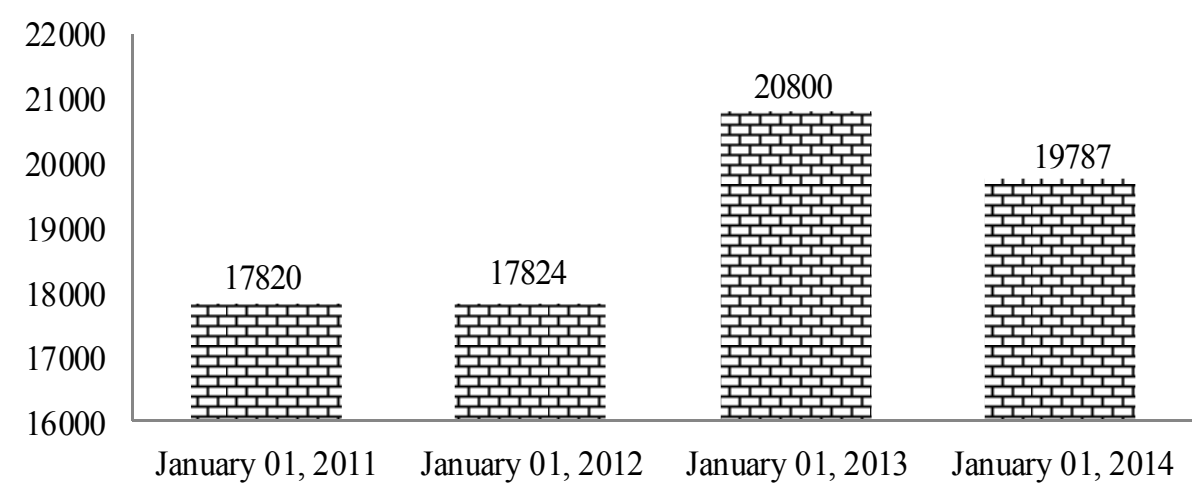

Figure 8 . The volume of budgetary appropriations for the implementation of the federal budget program on the small and medium-sized entrepreneurship support, billion rubles

Note. Compiled by the author according to the data of (Status report on the implementation of measures intended 
for supporting small and medium-sized enterprises during the years of 2010-2013 and on the main development directions of the small and medium-sized entrepreneurship for the short and mid-terms, 2014).

As the analysis shows, the investment activity of small businesses in Russia is focused on investing resources into the creation, reproduction, and acquisition of fixed assets (new construction, expansion, reconstruction, and technical re-equipment of facilities; acquisition of buildings, constructions, machinery, equipment, and tools; formation of the reproductive herd, perennial plantings, etc.). Thus, during the period under study, the volume of investment into the fixed capital of the small entrepreneurship sector is characterized by an increment of $34 \%$ (Figure 9).

Besides, a sufficient concentration of investment is traced in such activity areas as construction, real estate transactions that account for more than $50 \%$ of investments into the fixed capital of small entrepreneurship in Russia (Table 1). Investing within the fixed capital is directed primarily to the replacement of worn-out machinery and equipment at enterprises- $21 \%$, to the increase in production- $13 \%$, and to the production process automation-13\% (Figure 10).

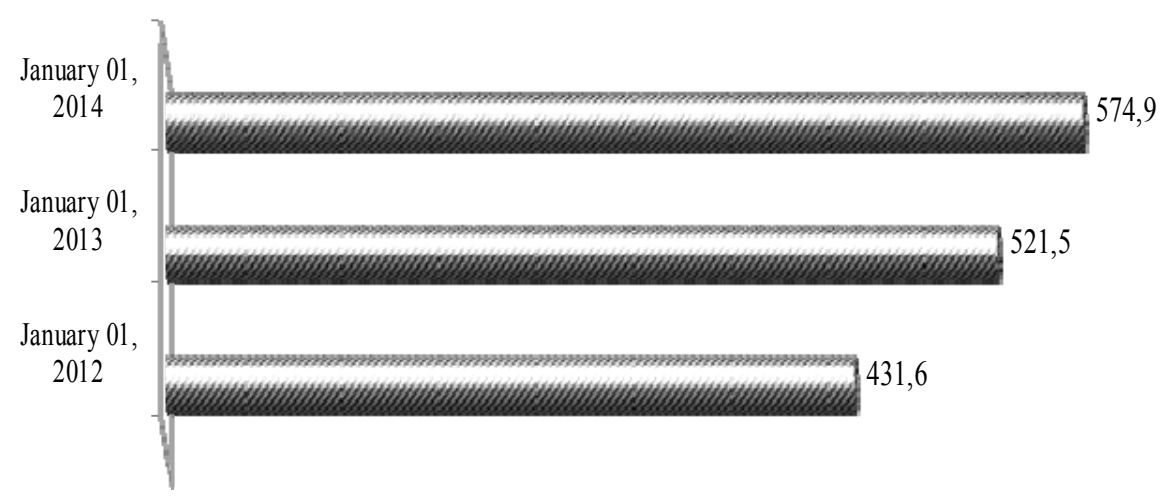

Figure 9. Volume indicators of investment into the fixed capital by small businesses of Russia, billion rubles Note. Compiled by the author according to the data of (Federal State Statistics Service, 2015).

Table 1. The structure of investments into the fixed capital of small businesses in Russia by types of activity, \%

\begin{tabular}{|c|c|c|c|}
\hline Type of business activity & $\begin{array}{l}\text { January } 01, \\
2012\end{array}$ & $\begin{array}{l}\text { January } 01, \\
2013\end{array}$ & $\begin{array}{l}\text { January } 01 \text {, } \\
2014\end{array}$ \\
\hline Agriculture, hunting and forestry & 17.2 & 16 & 13 \\
\hline Fishing and fish farming & 0.3 & 0.3 & 0.4 \\
\hline Extraction of minerals & 2 & 2.1 & 1.6 \\
\hline Processing industries & 14.5 & 16.3 & 14.1 \\
\hline Generation and distribution of electricity, gas and water & 0.4 & 0.7 & 0.6 \\
\hline Construction & 23.4 & 23.8 & 28.9 \\
\hline $\begin{array}{l}\text { Retail and wholesale; repair of motor vehicles, motorcycles, } \\
\text { household goods and personal demand items }\end{array}$ & 10.1 & 10.8 & 11.1 \\
\hline Hotels and restaurants & 0.7 & 0.7 & 1.2 \\
\hline Transport and communications & 3.9 & 3.7 & 3.8 \\
\hline - including communication & 0.4 & 0.5 & 0.3 \\
\hline Real estate transactions, rent and rendering services & 25.3 & 23.6 & 23.3 \\
\hline
\end{tabular}




\begin{tabular}{llll}
\hline - including scientific researches and developments & 0.4 & 0.3 & 0.3 \\
Education & 0 & 0 & 0.1 \\
Health care and rendering social services & 0.5 & 1 & 0.7 \\
Rendering other public utility, social and personal services & 0.9 & 0.9 & 1 \\
\hline
\end{tabular}

Note. Compiled by the author according to the data of (Federal State Statistics Service, 2015; Official Website of the Ministry of Economic Development of the Russian federation, 2015).

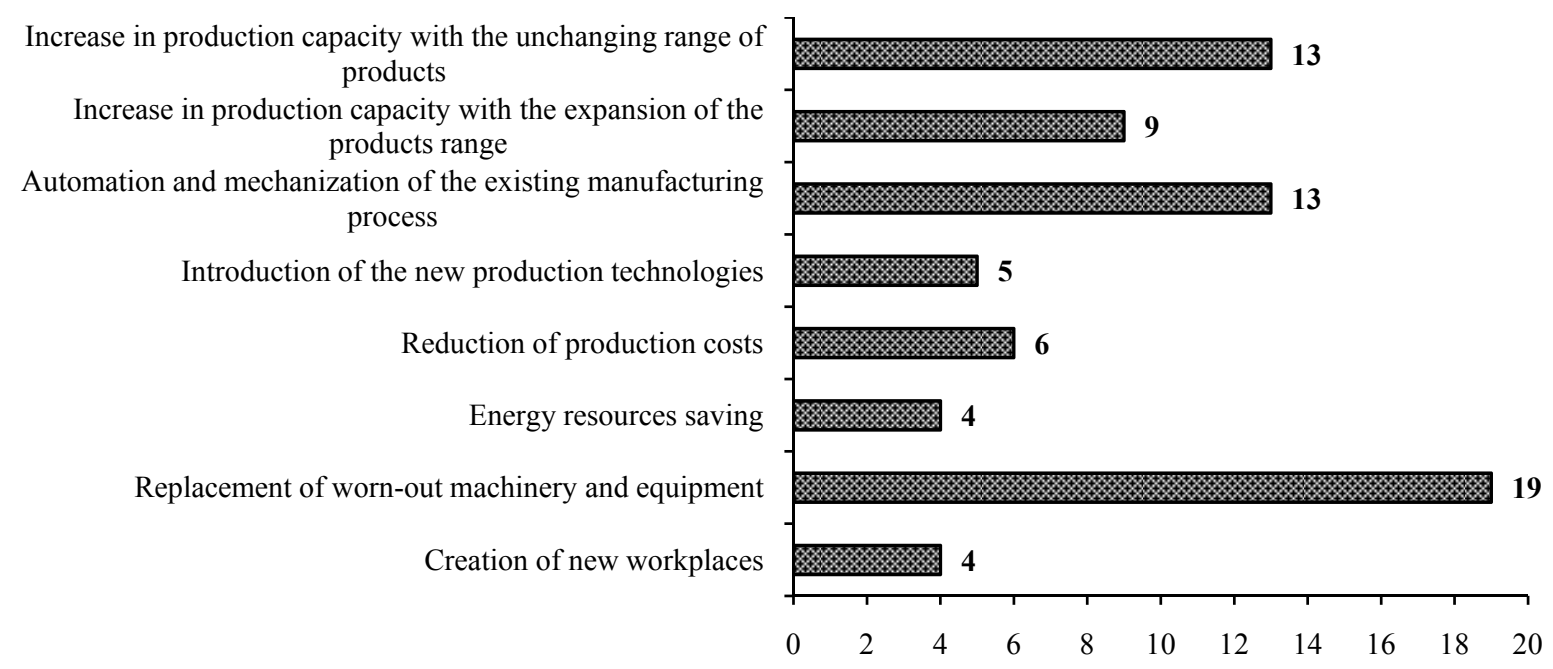

Figure 10. The functional purpose of investments into the fixed capital of small businesses in Russia as of January

$$
01,2014, \%
$$

Note. Compiled by the author according to the data of (Federal State Statistics Service, 2015).

The lack of differentiation of the lines of small businesses' investment activity, as well as its subordination to the manufacturing process, contribute to the lower investment activity.

The official statistical data on the destructive factors of investment activity among small businesses in Russia received through the expert method confirm the results reasoned within the study (Figure 11).

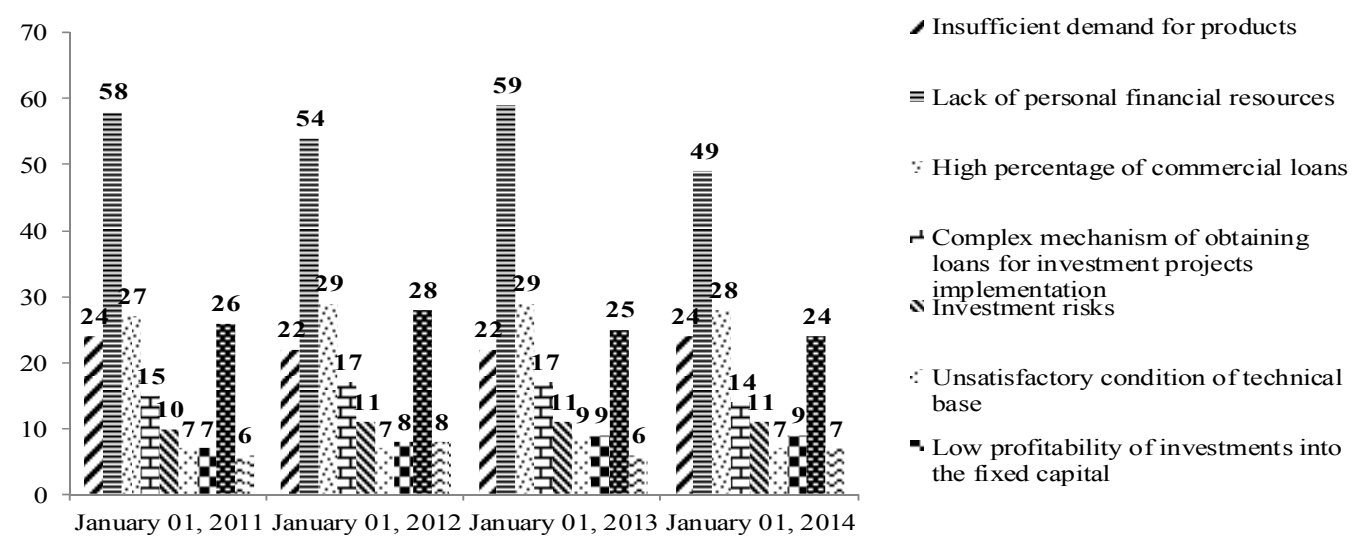

Figure 11. Quantitative characteristic of the factors constraining investment activity of small businesses in Russia, \% of the total number of organizations

Note. Compiled by the author according to the data of (Federal State Statistics Service, 2015). 
As evidenced by the data, the lack of equity capital is the leading destabilizing factor under the present conditions of the investment activity implementation for the majority of small businesses. The next constraining factors of equal importance are the high cost of debt capital, investment risks, and the low rate of return on the invested capital.

\section{Discussion}

The limited investment policy of small businesses demonstrates the ineffectiveness of investment activity management, as it does not perform the main principle of investment — provision of the most effective ways for implementing the investment strategy of an enterprise at different stages of its development, maximization of the enterprise market value, and increase in the welfare of its owners during the current and future periods. At the same time, the analysis of the investment activity condition of small businesses in Russia allows revealing a certain distinctive feature - the investment activity is reduced only to the maintenance of economic and industrial activity of the enterprises, which makes it necessary to search for new radical approaches in providing investment activity of small businesses and rational directions of its implementation, as well as building the resource provision capacity. Exactly these objectives should be the basis of the effectiveness of investment activity management in the Russian Federation.

One of the best ways to improve the efficiency of investment activity management of small businesses is to develop an investment strategy aimed at rationalizing and improving the productivity of financial resources usage (Sukhova \& Zhabunin, 2012; Barmashov et al., 2013). In the current circumstances, it is advisable to use the J. Franshon and I. Romane's matrix of financial strategies for the formation of the investment strategy of businesses. The matrix allows us not only to determine the current position of the company in terms of financial risks, but also to review the situation over time in order to determine the strategic direction of the business operation, depending on changes in key indicators of its activity (Stoyanova, 2014; Lisin, 2010).

The use of this matrix is based on the calculations of the following indicators: operating performance (OP), financial performance (FP), and financial and operating performance (FOP). According to the calculation results of the indicators presented, a business can be conventionally related to one of the matrix quadrants. It is also possible to determine the business' stage of financial development (Table 2) (Dorofeev, 2011).

The quadrants 1, 2 and 3 (the main diagonal of the matrix) relate to the equilibrium zone. Above the diagonal (quadrants 4, 5 and 6), the zone of successes is located, in which the values of indicators are positive, and the liquid funds are formed, i.e. the net cash flow is positive and the investment risks are minimal. Below the diagonal (quadrants 7, 8 and 9), the zone of deficits is located, wherein the consumption of liquid funds is observed, and the results of the operating, financial, and operating-financial performance of small businesses are negative (Goryainova, 2011).

Table 2. The J. Franshon and I. Romane's matrix of financial strategies

\begin{tabular}{lcll}
\hline $\begin{array}{l}\text { Stage } \begin{array}{r}\text { of } \\
\text { development }\end{array} \\
\text { OP financial }\end{array}$ & Deceleration & Stabilization & Growth \\
\cline { 2 - 4 } & FP $<0$ & FP $=0$ & FP $>0$ \\
\hline \multirow{2}{*}{ OP $=0$} & (1) Paterfamilias & (4) Rentier & (6) Parent company \\
& FOP $=0$ & FOP $>0$ & FOP $>0$ \\
OP $<0$ & $(7)$ Episodic deficit & (2) Stable equilibrium & (5) Attack \\
& FOP $<0$ & FOP $=0$ & FOP $>0$ \\
& (9) Crisis condition & (8) Dilemma & (3) Delicate equilibrium \\
& FOP $<0$ & FOP $<0$ & FOP $=0$ \\
\hline
\end{tabular}

The quadrants 4, 8 and 5 are associated with the formation of liquid assets by the enterprise (excess of current assets). The quadrants 7, 6 and 9 are associated with the consumption of liquid assets of the enterprise (current assets deficiency).

Horizontally, the financing activity result relates to the growth of borrowed funds of a small enterprise, that is, the value of financial performance changes from negative to positive. Vertically, the operating activity result relates to the implementation of an investment project by the company (Goryainova, 2011). 
The economic interpretation of the stages of financial development is presented in Table 3 (Dorofeev, 2011).

Table 3. Economic interpretation of the stages of business' financial development

\begin{tabular}{|c|c|c|}
\hline $\begin{array}{l}\text { Stage of financial } \\
\text { development }\end{array}$ & Economic interpretation & 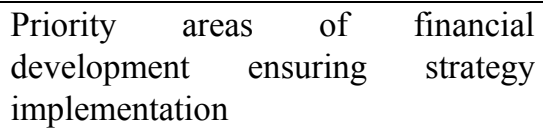 \\
\hline Formation & $\begin{array}{l}\text { Defining the objectives and directions of } \\
\text { financial development }\end{array}$ & $\begin{array}{l}\text { Analysis of the financial } \\
\text { environment }\end{array}$ \\
\hline Growth & $\begin{array}{l}\text { The most favorable stage of investment } \\
\text { activity. The company develops successfully, } \\
\text { efficiently uses its capital, the company's } \\
\text { value increases }\end{array}$ & $\begin{array}{l}\text { Accelerated growth of potential for } \\
\text { the formation of company's financial } \\
\text { resources }\end{array}$ \\
\hline Stabilization & $\begin{array}{l}\text { The company develops, but not efficiently } \\
\text { enough, "jerkily". Growth in the company's } \\
\text { value is not observed }\end{array}$ & $\begin{array}{l}\text { Ensuring effective distribution and } \\
\text { use of the company's financial } \\
\text { resources }\end{array}$ \\
\hline Deceleration & $\begin{array}{l}\text { The company develops inefficiently; the set } \\
\text { investment goals are not achieved. The } \\
\text { company's value decreases }\end{array}$ & $\begin{array}{l}\text { Formation of a sufficient level of } \\
\text { company security }\end{array}$ \\
\hline
\end{tabular}

In the present article, the Vector-Plast company (Novosibirsk) became the object of study with the purpose of the efficiency improvement of the investment activity management among small businesses based on the J. Franshon and I. Romane's matrix of financial strategies, and in order to develop conceptual and practical recommendations (The official website of the Vector-Plast Company, 2015).

With the help of the methodology by Stoyanova (2014) and according to the data of financial statements of the company, the following results were calculated: operating performance, financial performance, and operating-financial performance of the company for the period between January 01, 2012 and January 01, 2014 (Table 4).

Table 4. Indicators of the operating-financial performance of the Vector-Plast Company for the time period between January 01, 2012 and January 01, 2014

\begin{tabular}{llll}
\hline Indicator & $\begin{array}{l}\text { January 01, 2012, } \\
\text { thousand rubles }\end{array}$ & $\begin{array}{l}\text { January 01, 2013, } \\
\text { thousand rubles }\end{array}$ & $\begin{array}{l}\text { January 01, 2014, } \\
\text { thousand rubles }\end{array}$ \\
\hline Financial performance & -261 & -454 & 34905 \\
Operating performance & -58395 & -90661 & -194048 \\
Operating-financial performance & -58656 & -91115 & -159143 \\
Logical value of FP & FP $<0$ & FP $<0$ & FP $>0$ \\
Logical value of OP & OP $<0$ & OP $<0$ & OP $<0$ \\
Number of quadrant & 9 & 9 & 9 \\
\hline
\end{tabular}

Based on the obtained data, we can conclude that in 2011-2013, the index of FOP $<0$, which indicates a lack of funds needed for financing expenditures of the whole system of investment, production, and financial activities of the enterprise. This situation indicates a low level of liquidity, which adversely affects the solvency, as well as the overall financial position and organization of the small business' investment activity.

Based on the findings, let us define the position of the Vector-Plast company on the matrix of investment strategies and possible ways of its further development (Figure 12). 


\begin{tabular}{|c|c|c|c|}
\hline & $F P<0$ & $F P=0$ & $F P>0$ \\
\hline$O P>0$ & $\begin{array}{c}\mathbf{1} \\
F O P=0\end{array}$ & $\begin{array}{c}\mathbf{4} \\
F O P>0 \\
\end{array}$ & $\begin{array}{c}\mathbf{6} \\
F O P>0 \\
\end{array}$ \\
\hline$O P=0$ & $\begin{array}{c}7 \\
F O P<0\end{array}$ & $\begin{array}{c}\mathbf{2} \\
F O P=0\end{array}$ & $\begin{array}{c}\mathbf{5} \\
F O P>0\end{array}$ \\
\hline$O P<0$ & $\begin{array}{r}9 \\
2011-2013 \\
F O P<0\end{array}$ & $\begin{array}{c}\mathbf{8} \\
F O P<0\end{array}$ & $\stackrel{3}{F O P}=0$ \\
\hline
\end{tabular}

Figure 12. The matrix of investment strategies of the Vector-Plast company during the period between January 01, 2012 and January 01, 2014

Note. Calculated by the author according to the data of (Official website of the Vector-Plast Company, 2015).

The matrix of investment strategies of the small business under study gives reasons to conclude that during the time period between January 01, 2012 and January 01, 2014, the "Vector-Plast" company was in the quadrant 9 "Crisis condition" and was characterized as a company with unprofitable financial position accompanied by inefficient use of its investment potential. The company developed ineffectively and did not reach its objectives. That is, the enterprise was at the stage of deceleration characterized by a low level of company's liquidity and solvency.

In order to improve the efficiency of the investment activity, the Vector-Plast company is proposed with four possible options for its future financial development: the transition into the quadrants 2,3, 7 and 8 .

The company will move to the quadrants 2 and 7 in the event of the investment project implementation. Provided the sufficiently high rates of increase in the turnover, the company will be able to move to the quadrant 2 "Stable equilibrium", and at low rates of turnover growth it may move to the quadrant 7 "Episodic deficit". It should be noted that the optimal position for any small business within the matrix is the quadrant 2. Under these conditions, the company remains in the financial equilibrium and has the greatest number of possible changes in the financial position: the quadrants $1,4,7,5,3$ and 6 . The quadrant 7 is characterized by liquidity shortage due to the mismatch of the funds income and expenditure terms. Thus, there is a possibility of moving to the quadrants 2,8 and 9 .

In order to move to the quadrants 3 and 5, the necessary condition is a significant increase in debt capital, which is not always appropriate because of the high cost of the debt capital. The company will move into the quadrant 8 under the condition of its liquid assets formation and negative values of the operating and financial performance.

Thus, in 2011-2013, the Vector-Plast company was in the zone of deficits characterized by the consumption of liquid assets, so the values of the operating performance, financial performance, and operating-financial performance were negative. Such location of the enterprise within the matrix of investment strategies leads to the following conclusions: the company receives income, but does not fully use it for investment activity with the purpose of business development support; the company insufficiently uses the investment potential of borrowed funds; all the profits are directed only to the repayment of loans. The first priority direction for the strategic development of investment activity of the Vector-Plast company is its move to the quadrant 2 located in the zone of balance. In order to implement such a transition, optimization of the small business' capital structure may be reasonable alongside with directing borrowed assets into investment projects of high liquidity and rapid recoupment. Also the funds available on the company account should be used for short-term financial investments. The applied system of administrative activities will increase the investment activity efficiency of the company and will form the basis of its stable financial development.

Based on the above mentioned information, we come to a conclusion that the use of the J. Franshon and I. Romane's matrix of financial strategies is an effective instrument of prospective investment activity management for small businesses, which is subordinated to the implementation of objectives of its total development in the context of occurring significant changes of macro-economic nature, the system of state regulation of market processes, and the financial market environment. The advantage of this approach is its focus on the subject of financial analysis - the financial condition of a small business and the types of the financial decisions taken. It reflects clear strategic positioning of a small business (including its financial position) represented in the system of its operating principles and objectives, the mechanism of interaction between the subject and object of management, the nature of relationship between the elements of economic and organizational structures and forms of their adaptation to the constantly changing environmental conditions. 


\section{Conclusion}

Based on the conducted research, we come to a conclusion that the contemporary resource provision of the investing activities among small businesses in Russia is limited due to the lack of sufficient volumes of equity capital and budget subsidies formation; the direct dependency on the bank credit resources is traced, which significantly reduce the investment activity of small businesses due to their high value. The study reveals that the non-differentiated nature of the investment directions among small businesses in Russia is subject to the subordination of economic and industrial functionality of small entrepreneurship, which proves the ineffective management of investment activities performed by economic entities. In view of the identified features of the investment activities executed by small businesses, the expediency of the investment strategy development of enterprises is adequately supported on the basis of the J. Franshon and I. Romane's matrix of financial strategies as an approach to improving the process of investment management of small businesses based on the rational use of their financial resources. Practical application of the investment strategy development on the example of the Vector-Plast small business provides an opportunity to identify the advantageous characteristics of the improvement of the approach to the investment activity management of the company based on the matrix of financial strategies. These strategies are to identify the major promising directions of investment with account of determination of the actual financial possibilities of a business entity. Since this approach does not take into account sectoral peculiarities of the small businesses' operating activity, the priority areas for further research were determined, which will be focused on the study and development of methodological approaches to improve the efficiency of investment activity management of small businesses in view of the following factors: the operation area, the financial condition and potential of the business, the level of innovation, etc.

\section{References}

Barmashov, K. S., Barmashova, L. V., \& Viktorova, T. S. (2013). Formation of the economic mechanism of innovative-investment process under the condition of sustainable development of an enterprise (p. 120). Viazma: FGBOU VPO "MGIU" branch in Viazma.

Bennett, A. (2015). McDowell Proven techniques for managing capital. Setting up the system of risk management. Retrieved from http://www.virtuosclub.ru

Bocharova, O. N. (2014). Perspective directions of development of small and medium-sized businesses in the new environment. Sotsialno-Ekonomicheskie Yavleniya I Protsessy, 6, 6-15.

Bouchaud, J. P., \& Potters, M. (2009). Theory of financial risk from statistical physics to risk management (p. 219). UK: Press syndicate of the university of Cambridge.

Dorofeev, M. L. (2011). Features of applying the J. Franshon and I. Romane's matrix of financial strategies within the strategic financial analysis of a company. Finansy $i$ Kredit, 23, 51-56.

Erden, L., \& Holcombe, R. (2005). The effects of public investment on private investment in developing economies. Public Finance Review, 5(33), 575-602. http://dx.doi.org/10.1177/1091142105277627

Federal portal for small and medium entrepreneurship. (2015). Ministry of Economic Development of the Russian Federation. Retrieved from http://www.smb.gov.ru/statistics/officialdata/

Galliamova, D., \& Kashin, A. (2011). Development of innovative and investment activities in the metalworking enterprises (Monograph) (p. 138). St. Petersburg: Publishing house of St. Petersburg University of Management and Economics.

Goryainova, S. B. (2011). Staging the financial development of the enterprise in the process of financial strategy development. Innovvatsiyna Ekonomika, 18, 67-269.

Integrated Small-Enterprise Development Strategy. (2015). Department of Trade and Industry. Retrieved from http://www.hopeafrica.org.za/downloads/ small\% 20business \%20strat.pdf

Khanna, N., \& Tice, S. (2011). The Bright Side of Internal Capital Markets. Journal of Finance, 5, 1489-1531.

Khokhlova, G. I. (2013). The main features of innovation and investment activity of small and medium-sized entrepreneurship and the factors influencing its development. Mir Nauki, Kultury, Obrazovaniya, 6(43), $36-42$.

Korkmazova, M. K. (2015). The problem of investment attractiveness of small business enterprises. Retrieved from http://www.scienceforum.ru/2013/pdf/ 8838.pdf

Lisin, V. V. (2010). Investment support of small business: Problems and prospects. Herald of Tomsk State University, 340, 149-152. 
Metelkin, A. E. (2012). Small business enterprises: Current condition and development tendencies. Molodoy Ucheny, 10, 129-132.

Mukhametaltypov, R. F., \& Dadakhanova, R. R. (2013). Current condition of small entrepreneurship in Russia. Molodoy Ucheny, 5, 359-360.

Official website of the Bank for Development and Foreign Economic Affairs. Bank for Development. Retrieved from http://www.veb.ru/

Official website of the Central Bank of the Russian Federation. Retrieved from http://www.cbr.ru/

Official website of the Federal State Statistics Service. Retrieved from http://www.gks.ru/

Official website of the Ministry of Economic Development of the Russian Federation. Retrieved from http://economy.gov.ru/

Official website of the Vector-Plast company. Retrieved from http://www.vektorplast.ru/

Resolution of the Government of the Russian Federation "On the distribution and provision of subsidies from the federal budget of the Russian Federation for the state support of small and medium-sized entrepreneurship including peasant (farm) economy" dated 27.02.2009 \#178. Retrieved from http://www.rosavtodor.ru/activity/economy/98/99/2391.html

Pinkovetskaya, Y. S. (2013). On the estimation of investments in small and medium entrepreneurship. Korporativnye Finansy, 1(25), 44-54.

Report on the implementation of measures intended for supporting small and medium-sized enterprises during the years of 2010-2013 and on the main development directions of the small and medium-sized entrepreneurship for the short and mid-terms. (2014). Federal portal for small and medium-sized entrepreneurship. Ministry of Economic Development of the Russian Federation. Retrieved from http://www.smb.gov.ru/statistics/officialdata/

Savchenko, D. A. (2013). Improving the financial instruments of government support for investment activity of small businesses under conditions of the WTO accession. Herald of VolGU, Series 9, 11, 43-45.

Shweta, M. (2012). How to create and implement your financial strategy? Personal Money, 7, 15-19.

Small and Medium Enterprise (SME) finance (2015). Financial systems development. Retrieved from http://www.gfa-group.de/584956/Factsheet_SME-Finance_E.pdf

Stoyanova, E. S. (2014). Financial Management: Theory and Practice (6th ed.). Moscow: Publishing House "Perspektiva".

Sukhova, S. M., \& Zhabunin, A. Y. (2012). Development of measures concerning the support of investment and innovation development of small business based on the SWOT-analysis tools. Herald of the AGTU, 2, 116-121.

Wilcox, J., Horvitz, J. E., \& di Bartolomeo, D. (2012). Investment Management for Taxable Private Investors (Monograph) (pp. 86-89). Research Foundation of CFA Institute.

Xuewen, L. (2013). Analysis on Enterprise Financial Stratagem in Different Lifecycles (pp. 833-836). School of Economics and Business of Yantai University.

Yashin, S. N., Yashina, N. I., \& Koshelev, E. V. (2010). Financing of innovations and investments of enterprises (Monograph) (p. 245). Nizhny Novgorod: Publishing house VGIPU.

\section{Copyrights}

Copyright for this article is retained by the author(s), with first publication rights granted to the journal.

This is an open-access article distributed under the terms and conditions of the Creative Commons Attribution license (http://creativecommons.org/licenses/by/3.0/). 